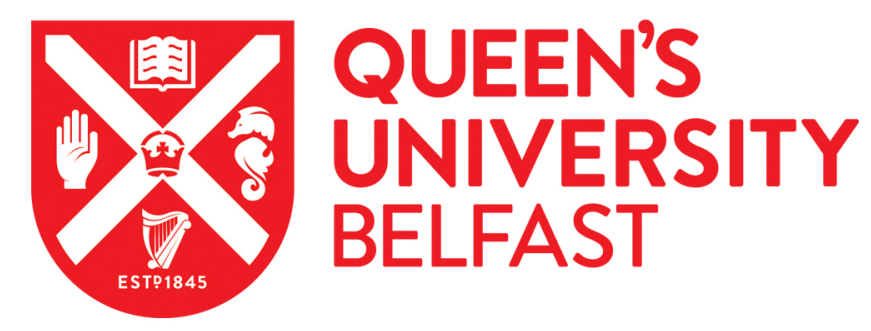

\title{
Female narratives of 'new' citizens' belonging(s) and identities in Europe: case studies from the Netherlands and Britain
}

Ghorashi, H., \& Vieten, U. M. (2013). Female narratives of 'new' citizens' belonging(s) and identities in Europe: case studies from the Netherlands and Britain. Identities: Global Studies in Culture and Power, 19(6), 725-741. https://doi.org/10.1080/1070289X.2012.745410

Published in:

Identities: Global Studies in Culture and Power

Document Version:

Peer reviewed version

Queen's University Belfast - Research Portal:

Link to publication record in Queen's University Belfast Research Portal

\author{
Publisher rights \\ (C) 2013 The Authors \\ This is an Accepted Manuscript of an article published by Taylor \& Francis in Identities on 02 January 2013 , available online: \\ http://www.tandfonline.com/doi/abs/10.1080/1070289X.2012.745410.
}

\section{General rights}

Copyright for the publications made accessible via the Queen's University Belfast Research Portal is retained by the author(s) and / or other copyright owners and it is a condition of accessing these publications that users recognise and abide by the legal requirements associated with these rights.

Take down policy

The Research Portal is Queen's institutional repository that provides access to Queen's research output. Every effort has been made to ensure that content in the Research Portal does not infringe any person's rights, or applicable UK laws. If you discover content in the Research Portal that you believe breaches copyright or violates any law, please contact openaccess@qub.ac.uk. 
Female narratives of 'new' citizens belonging(s) and identities in Europe: case studies from the Netherlands and Britain

Halleh Ghorashi (VU Amsterdam) and Ulrike M Vieten (University of Sheffield)

\begin{abstract}
Public discourses on citizenship, identity and nationality, which link geographical border and the boundaries of a political community, are infused with tensions and contradictions. This paper illustrates how these tensions are interwoven with multilayered notions of home, belonging, migration, citizenship, and the individual 'longing just to be', focusing on the Dutch and the British context. The narratives of a number of Dutch and British women, who either immigrated to the respective countries or were born to immigrants illustrates how the growing rigid integration and assimilative discourses in Europe contradict individual an anchoring in national and local communities. The narratives of women participating in these studies show multilayered angles of belonging presenting an alternative to the increasingly proposed fixed notion of positioning and national belonging. The female 'new' citizens in our study tell stories of individual choices, social mobility, and a sense of multiple belonging in and across different communities.
\end{abstract}

Keywords: Dutch and British citizenship, migration, de-territorialization, politics of belonging, female narratives, 'civic integration' in Europe 


\section{Introduction}

The British sociologist T.H. Marshall (1950), who advocated a model of social cohesion, coined the three concepts of civil, political and social citizenship. The notions of ‘cultural citizenship’ (Stevenson 2003) and ‘cosmopolitan citizenship’ (Linklater 2002) add further dimensions to current debates on citizenship, reflecting on difference, diversity and multiculturalism, and building up a well known vocabulary referring to minority group recognition in an increasingly globalized world. Lister et al. (2007: 4) argue that “[...] various forms of regimes- welfare, care, gender, citizenship and migration - dovetail together to constitute formal citizenship and to frame the lived experience of gendered (and racialised) citizenship in different ways.” Whereas these considerations address conceptual aspects of an increasingly multi-layered model of citizenship (Yuval-Davis and Werbner 1999), current integration policies in European countries are based on rigid citizenship tests. National integration policies enforce language acquisition and domestic Leitkultur values, all in all claiming to represent a liberal notion of Western civilization while pushing aggressively for domestic acculturation of newly settled citizens and migrants. Prominently, the growing exclusionary discourse in Europe presents the culture of Muslim migrants as different from and even inferior to Western culture. Stolcke (1995) refers to this dichotomization of cultures as 'cultural fundamentalism', which is based on a homogeneous, static, coherent, and rooted notion of culture. The gendered dimension of this culturalist discourse in the Netherlands, for example, relates to the image of Muslim women as suppressed by their cultures and especially by the men in their lives. Focusing on the Dutch and the British context, this paper illustrates the ways in which home, belonging, and the 
individual 'longing just to be’ are intertwined. Social relations, we argue, are not merely confined to the boundaries and borders of one particular nation state (Mitchell 1997; Kim-Puri 2005). A new place can become home as long as social spaces are available that allow individuals to thrive with respect to personal development, e.g. work, political engagement, friendship and intimate relationships. Anthias (2006: 21) argues “[b]elonging and social inclusion (rather than cohesion) are closely connected, although this does not mean that belonging itself brings about social inclusion (or cohesion). It is, however, through practices and experiences of social inclusion that a sense of a stake ${ }^{\mathrm{i}}$ and acceptance in a society is created and maintained.” Hence, we need national policies and cultures of 'Letting-Be' (Kostakopoulou 2010: 838) replacing the restrictive, civic integration agenda aimed at migrants. Kostakopoulou criticises the current integration discourse and policy in Britain, but highlights that its goal of social cohesion is intertwined with similar developments in other European countries, among others, the Netherlands (2010: 830). What she calls a policy of 'Letting-be' is a state policy developing “a nonracialised frame of community that welcomes migrants and treats them fairly because it recognises that migrant incorporation is a long-term and multi-faceted process that takes place while people are 'getting on with their lives' - that is they become enmeshed in social life and form independent relations” (2010: 838). Having this more positive outlook in mind, how can we capture these processes of 'getting on with their lives', and also illustrate the gendered dimensions to citizenship, migration and nation settlement/ belonging that shape these processes in different European countries?

In this paper we try to capture some conceptual, but also empirical meanings of what new citizenship entails and how identities unfold in the context of home, migration 
and belonging. We do so with respect to the narratives of a number of Dutch and British women with a migration ${ }^{\mathrm{ii}}$ background. First of all, we theoretically anchor the notion of belonging and the tension inherent to recent debates on citizenship, identities and the positioning of migrants in the Netherlands and Britain. Secondly, a number of concrete illustrations are given using personal narratives from the empirical studies. Finally, we draw together the specificities of the two national settings: their commonalities and their particularities. The following section begins with a theoretical framing of the notion of gendered belonging with reference to territoriality, nationality and citizenship in the context of migration.

\section{De-territorialized be-longing, home making and the challenge of being a female} citizen

Citizenship is achieved through political membership to a nation state, yet, although legally framed, it does not guarantee a sense of belonging. 'Politics of belonging encompass and relate both citizenship and identity, adding an emotional dimension which is central to notions of belonging' (Yuval-Davis Et. El. 2006: 1). The notion of 'politics' stresses "both sides of the inclusion/exclusion dynamic” (Geddes and Favell 1999: 11) and, as a result, relates to the ideological construction of symbolic boundaries regarding a national community.

Various social categories constitute a structural agenda of hierarchically instructed participation in communities and of communities. Prominently, the social divisions of gender, class, ethnicity, race (Anthias 1999) and - with respect to its politicized meaning in the $21^{\text {st }}$ century - religion - are central to understanding social practices and processes that affect identity. Lister (1997) argues that the nation-state just as well as any community consists of boundaries and 'allocative processes' (1997: 43). 
These processes operate simultaneously. The term boundary is meant to signify political borders, but also ‘social and cultural barriers’ (Entrikin 1999: 272), which erect symbolic fences between an 'us' and 'them'. Thus, the demand to identify with the dominant cultural discourse could imply the 'promise' to be transformed from the other/them into 'us'. These hegemonic discourses are informed by a notion of a singular rooting of belonging which is based on what Malkki (1995) calls ‘the sedentary bias’. Although our era is defined as one of fluidity and mobility (Bauman 2000), dominant discourses on integration and belonging in Europe are primarily informed by 'the national order of things' in which 'rootedness' in a culture or a geographic territory is considered as a natural and normal feature of humanity (Malkki 1995: 509). In this sense, home is directly related to a physical space and often equated with the borders of a nation state. From a non-sedentary point of view, home is de-territorialized and reterritorialized as it becomes a space in which one is able to find satisfaction by improving oneself, or in which one can express oneself freely. The sense of belonging refers then to a particular positioning in which different places overlap (Appadurai 1997;; Hall 1990, 1992; Malkki 1995). The meanings attributed to this sense of belonging are diverse, multi-layered, and dynamic because they are contextual and situational. Being at home is not linked to a physical space of the past, but to a domain where the past and the present are mediated through present choices, chances and networks. "One is at home when one inhabits a cognitive environment in which one can undertake the routines of daily life and through which one finds one's identity best mediated-and homeless when such a cognitive environment is eschewed” (Rapport and Dawson 1998: 10). This differentiation is also made by Brah (1996: 197) by her distinction between 'feeling at home' and declaring a place as home. 
This brings us to Deleuze’s and Guattari’s (1987) term 'deterritorialization’ capturing the transformative space created when individuals leave the nations and places in which they grew up. Importantly, the moment of de-territorialization should be understood as followed by a process of re-territorialization (Deleuze and Guattari 1987). This moment could be regarded as initiating a life-long transformation process that becomes a different spatial site of social practices. Here, the focus is on a politically framed 'process of becoming' (Kannabiran 2006) implying that different national identities and realities are absorbed and could merge as a state of mind and being on its own (sui generis), which does not have a place with binary, either/or nationalities (Vieten 2006). In this case, agency refers to the "capacity to be reflexive about their situation - their 'discursive consciousness' - and to act upon it to make a difference” (Zanoni and Janssens (2007: 1376). As a result, agency is located in a dialectic relationship between social structure, situated in social relations and the individual self. This underscores the idea that female new citizens can be both the objects of discursive power relations and the agents of their own lives.

Both the Netherlands and Britain are shaped by a history of colonialism, international warfare, and commercial trade, albeit in different ways. What is of core importance is that in the 1980s, the Netherlands was the only continental European country that, like Britain, developed a coherent domestic policy of anti-discrimination law and multiculturalism. At the same time, the specific and divergent histories of society and state building deliver a contrasting pattern: 'Englishness’ refers to a majority ethnicity of white Anglicans. Minority indigenous ethno-national groups of Scots and Irish fought against this hegemony on the British Islands for centuries. Since the late $20^{\text {th }}$ century English hegemony is challenged politically by devolution and postcolonial critique. What is apparent and interesting to further comparative analysis is 
how far a more inclusive notion of British nationality developed alongside British multiculturalism. In what ways does this symbolic space include feelings of belonging and individual capacities to act on citizenship? Did this happen in the Netherlands in a similar manner? How far do different national pathways to citizenship, and divergent notions of ethno-national political community impact on social cohesion across Europe, and, specifically, on the sense of belonging of individual females who are 'new' citizens? It is this frame of commonality and particularity that makes the comparison of these two EU member states important. It delivers a structural background to the ways in which visible minorities, in particular 'migrant' women, are still regarded in national mainstream debates as cultural and ethnic outsiders falling behind when it comes to the gendered emancipation standards' of Western societies, making it necessary to explore to what degree 'new' female citizens are empowered agents ${ }^{\mathrm{iii}}$ challenging these dominant perceptions. In the next section, the situation in the Netherlands will be outlined and discussed.

\section{Layered meanings of 'being Dutch'}

Various studies on migrants and refugees in the Netherlands show that in spite of having legal citizenship many feel discursively excluded and not considered as belonging to the imagined construction of the Dutch nation (Essed and Trienekens 2008; Vasta 2007). There are several factors - conveying collective, structural and symbolic dimensions -- that contribute to the formation of discursive exclusion.

The Dutch discourse of migration has shifted several times in recent decades. Until 1980, Dutch state policy towards new migrants (as opposed to the migrations from Dutch ex-colonies) was formed with the idea that the present migrants would one day return to their home countries. Historically, this had to do with the migration of so- 
called guest workers to the Netherlands at the end of the 1950s when there was a great shortage in the labour market. With the migrants' return in the back of policymakers' minds, policy was mainly aimed at maintaining the cultural identity of migrants rather than their integration into Dutch society until 1980. In the 1980s, the Dutch government shifted its policy regarding guest workers when it realized that migration, once viewed as temporary, had gained a more permanent character. The status of this group changed to '(im)migrant' (Lutz 1999) and the focus of the policy changed increasingly towards integration instead of accommodating cultural identity of migrants. Since 1998, we observe a turn towards mandatory civic integration which is considered to be a move away from multiculturalism (Joppke 2004) or a shift towards assimilation (Vasta 2007).

In spite of the significant shifts in the policy we can observe that certain basic assumptions within the Dutch discourse on migration have remained consistent. One of these assumptions is what we referred to earlier as 'the sedentary bias' (Malkki 1995) in understanding migrants' positioning. This sedentary bias considers the 'rootedness' of migrants in their cultural background and/or the geographic territory of their country of origin as a natural and normal feature of their positioning. This essentialist and static approach of identity and home leads to the following contradiction: migrants are legally included but discursively excluded from belonging since they are (perceived as) loyal to their 'roots' and not 'real Dutch'. The use of the two terms allochtonous /autochtonous is a daunting proof of this distinction. According to the Dutch Government Central Bureau of Statistics (CBS) an allochtonous is defined as a person with at least one parent born abroad, as opposed to native Dutch who are referred to as autochtonous. A further distinction is made between Western and non-Western allochtonous.

In spite of the persistence of this othering discourse concerning migrants, it is mainly since the turn of the century that we observe extreme negative approaches 
towards the culture and religion of migrants (in particular of Islamic migrants) in the public space. The events of September 11, 2001 awakened a latent discomfort towards migrants within Dutch society which Entzinger (2003: 71) refers to the feeling of “a silent majority tired of multiculturalism”. There were two political murders in two years (Fortuyn in 2002 and Van Gogh in 2004) in the Netherlands that added fuel to this growing negativity. In 2002, Pim Fortuyn - by then an influential anti-Islam politician was murdered by a native Dutch animal activist. The 2004 murder of the filmmaker and columnist Theo van Gogh by a young Moroccan-Dutch man provided new justification for even more extreme negative emphasis on Islam and the questioning of the position of Islamic migrants in the Netherlands. A country with a long-standing self-image combining multicultural promise with openness, tolerance, and liberalness came increasingly under the throes of fear, protective of its 'national identity' (Duyvendak, Engelen and de Haan 2008). This protective attitude has had consequences for other migrant groups as well. The most recent example is the controversy over the website of the Party of Freedom (PVV) inviting people to report negative experiences with Poles and other Eastern European. By now, the European Parliament has urged the Dutch Prime Minister Rutte to condemn the website. ${ }^{\text {iv }}$

This increasingly exclusionary discourse clearly has gendered framing. Until the start of the new millennium, migrant women (particularly Muslim women) were invisible within the Dutch dominant discourse. They fell outside the constructed dichotomies: emancipation policies focused on white women and integration policies on non-white men (reference concealed). Influenced by the Black feminist movement in the United States and inspired by the work of Audre Lorde and others, many activists and scholars started a struggle in the Netherlands - particularly in the 1980s and 1990s - to make the situation of black and, later, migrant and refugee women visible (citation 
concealed). In spite of various initiatives during that time, the focus of integration and emancipation policies remained the same. Since the start of this century, this invisibility morphed into extreme visibility and Ayaan Hirsi Ali's plea for women's liberation from Islam was a crucial factor (Vasta 2007). This shift towards an extensive and explicit focus on the emancipation of migrant women, in particular Islamic women, was remarkable because of its culturalist assumption (Roggeband and Verloo, 2007). The assumption was that Dutch women were already emancipated and did not need any explicit attention policy-wise, while migrant (particularly Muslim) women were in need of explicit help in order to gain emancipation. The intersection of gender, ethnicity, and religion in this assumption serves as a marker to strengthen boundaries of otherness with Muslim women's suppressed position at the core. The rigidness of thinking in terms of absolute structures of difference does not leave room for agency of Muslim women who are assumed to be absolutely suppressed within the structures of their culture or religion. In this way, the dominant Dutch discourse makes women with Islamic backgrounds icons of otherness.

To investigate how this discursive space influences the sense of belonging of women with different backgrounds (Surinam, Turkey, Morocco, Iran and Iraq), several intensive writing sessions were organized in 2008. Narratives of the women produced in these sessions were used to understand their positioning in terms of identity and belonging. Most narratives emphasized the impact of the increasingly negative discourse on their sense of belonging to the Dutch society. The age of the women varied from 30 to 60 years old. The majority were between 45-50 years old. Most of them had enjoyed higher education and had been active for years as professionals in Dutch society. The names are real names. 
Farzaneh, an Iranian-Dutch woman, who came to the Netherlands in 1983, states:

"I never felt that I was an allochtonous. For a long time I thought that the term allochtonous refers to someone who does not speak the language and is not adapted to the Dutch culture. After the murders of Fortuyn and van Gogh, this concept gained a new meaning for me. Then I realized that I was also seen as allochtonous. Before that time I was just Farzaneh, completely integrated in the society. But then I realized that I was treated differently than the autochtonous Dutch [or native Dutch]”.

This quote shows the negative connotation of the concept allochtonous. As mentioned earlier, although the concept formally refers to all Dutch citizens who have origins elsewhere, in the public discourse it is mainly used for migrants of colour distinguishing them from the 'real', native Dutch (Essed and Trienekens 2008).

In spite of this sense of 'othering', women tried to transform their feeling of pain and anger in a constructive manner to struggle for a better society as was revealed in a number of the stories. A positive take on negative experiences gave them the power to move on. The story of Oualifa, a Moroccan-Dutch woman who came to the Netherlands with her mother at the age of four to join her father who was working in the country as a guest labour migrant, illustrates this very well. She describes how difficult it was for her to resist taking on a defensive attitude to counter the increasingly negative discourse towards migrants with Islamic backgrounds that followed the events of September $11^{\text {th: }}$

"It irritated me a lot that I constantly had to defend the acts of a small minority for whom I was not responsible. I often realized that I was talking to a closed door. At some point I decided not to have a defensive attitude anymore but chose to confront the situation. Since I was living in a white neighbourhood, I started to emphasize 
the joint-responsibility of the native Dutch in building a society where everybody feels at home”.

The stories also showed a range of feelings from up-rootedness to alternative forms of belonging. A nice example of this is the story of Irish, who came to the Netherlands from Surinam as a child and became a successful social worker in the Netherlands. She starts her story with this passage:

"When I saw how one of my co-travellers - an elderly woman - was sniffed and jumped at by a big sheepdog after leaving the airplane, I realized that I had to go through all the phases of $100 \%$ control that is meant for all the planes from Paramaribo. My estimation was right. I was also treated like a potential criminal and had to show my passport and tell them about the things I did in Surinam and to show them my ticket. I refused to do the last one. I told them that I did not need a ticket to leave an airplane but to board one. [...] That experience at Schiphol made it clear to me that the Netherlands is not my home, and it will never become one. Maybe I had experienced the Netherlands as home far in the past, but that has changed. I live here and have built a life for myself. I got chances in life by being brought up here, but this is not my home. I feel at home with my family, my friends and my country mates, and at certain points with some of my colleagues and in my house. But this country is not my home”.

Irish's story shows how particular incidents at the airport led to the manifestation of her sense of non-belonging in the Dutch society. It is tied to the fact that the discourse in the Netherlands has become more exclusive as well as more insulting to its residents with non-western migration backgrounds who are visibly different. The reference to the past sense of a possible belonging to the Netherlands shows how this feeling is connected to and influenced by the growing discourses of exclusion even though their focus is 
mainly on Muslim migrants. This quote also shows the layers of territorial, deterritorial, and re-territorial notions of home. While crossing the Dutch border, Irish encounters the territorial dimension of what Dutch society has become and means to her. She refuses to be Dutch when she feels that she is not treated with dignity because of her background. She also detaches her feeling of belonging from the Dutch territory by making connections to the people she feels close to. Those feelings become reterritorialized in several spaces -- explicitly her own home in the Netherlands, and her ties to her compatriots in and from Surinam.

Various stories show the individual struggles of these women with contradictory feelings of in-betweenness and interrelatedness. They show multi-layered feelings of belonging to several places in which time and space overlap. Another example of this multi-layered assemblage of belonging is expressed by Samira. Samira is a successful Moroccan-Dutch entrepreneur, who arrived as a young girl in the Netherlands. The family joined the father, who came some years earlier as a "guest labour" migrant. She narrates:

"In the passing of years I have been asked many times whether I felt at home in the Netherlands. I found and find this a stupid question. I was brought up here and think and dream in Dutch. But I did not get this question only here in the Netherlands, also in Morocco. Sometimes I ask myself the question [...] what would have happened to my life if my family would have stayed in Morocco. Would I have had the chances to become the person I am now? I do not think so. At the same time, I know that I have gained a lot from my family in Morocco. I believe in the power that I have inherited from my parents. It was a great offer for them to take the step to migrate to the Netherlands. The richness of this for me was 
to be not only from the Netherlands but also share the world that my parents brought with them"

This passage in Samira's story shows how unhappy she is with the questions about her emotional connection to the national boundaries of both the Dutch and Moroccan nation states, giving the impression of being torn between both sides. After this initial negative reaction she takes a positive turn by expressing what both contexts mean to her. She also goes one step further and de-territorializes the notion of belonging by talking about spaces of opportunities related to the possibilities of self improvement in the present and the past. In her narrative, time and space overlap, allowing her to feel at home in both the Netherlands and Morocco.

As these concrete passages underline, female 'new citizens' in the Netherlands have to balance their multi-layered and plural experiences of national and cultural belonging with the perceptions of the dominant Dutch culture. Whereas the narratives show rich and complex identities, the dominant discourse demands conformity to a mono-linear Dutch ‘ethnoscape’ (Appadurai 1996). What we see implicitly in Samira’s story and more explicitly in others, is that many women connect their source of belonging to the space where they can improve themselves and be free of various forms of restrictions they may face because they are female. In their narratives they emphasize that they are not passive victims of their cultures but active agents of change in their own lives and also contributors to the many spaces of which they are part.

In the next section, we discuss some gendered experiences with belonging of female South Asian British citizens. As in the Dutch study the women interviewed in London and in Leeds share a similar middle class background either through educational achievements or family heritage, and they also work as professionals or academics. Further, biographical experiences with a temporary stay in different 
geographical regions of the country and the particular meaning of cosmopolitan and multicultural London as the prominent point of British national pride (Vieten 2012) shape the way 'national identity' is perceived.

\section{South Asian Brits: 'being a Londoner' or 'from Yorkshire'}

First, we will sketch some characteristics of London as a signifier of the multicultural notion of the British nation, and the connotations ascribed to some cities in North England. This helps to contextualize how the interviewees relate to the locality of their residence, to the British nation, and also to interwoven layers of further group identities. As Alexander et al. (2007) stress "local, heterogeneous and contingent networks of family, friends and neighbours” (2007: 788) provide the personal space to develop "emotion, trust and security” (ibid.). These, 'personal communities' (ibid.) exist alongside and as the basis for what is understood as ‘imagined communities’ (Anderson 1991). The argument of a ‘personal space’ will be explored within the regional context of biographical de-territorialization and notions of belonging.

The notion of the city of London conveys a specific vernacular cosmopolitanism (Nava 2007) that could be understood as an outcome of the long lasting history of global commercial trade on the one hand, and a specific metropolitan culture of openness and indifferent tolerance towards strangers, on the other. The London bid for the 2012 Olympic Games in 2005, for example, made a strong claim of a diverse British multicultural nation. One day after the announcement of its success, on July 7, 2005, the suicide attacks on London’s public transport vehicles resulting in the killing of 56 people turned this view on its head. The violent extremists came from Yorkshire, more precisely from Leeds and Bradford. A new form of violent religious 
and so called 'home grown' extremism came to the fore. Attention to the social differences in England, were highlighted with the theme of 'spatial segregation' that had come up in the context "of the 2001 race riots ${ }^{v}$ which swept northern cities such as Oldham, Burnley, Bradford and Leeds” (Kim 2010: 128). Kim (2010: 128) observes in a reflection on the former Labour Government; "New Labour stressed the lack of deliberation among different cultural groups in the form of segregated residence rather than poverty and economic deprivation in the form of slum residence”. This is relevant as some of the very much classed structures are visible in poverty-driven, spatial segregation encompassing a culturalising discourse targeting ethno-racial minorities (Vieten 2013 forthcoming). The latter also leads to gendered assumptions of how, for example, Muslim women cope with speaking and learning English, or how South Asian girls are forced into arranged marriages (Yuval-Davis et al. 2005; Alexander et al. 2007). While the notion of 'multiculturalism' refers to a communitarian perspective connecting the post-colonial presence of ethnic and racial minority groups with a notion of different 'cultures', this focus has recently become one of religious affiliation as the basis for community cohesion. As with the situation in the Netherlands, orthodox Islam and 'Muslim belonging' have become extremely politicized: increasingly, moderate Muslim community activities receive public funding hinting at the British government's strategies to use soft 'gendered community' tools to combat radical and extremist Islamist convictions. Further, there is a rise in profiling and policing of visibly orthodox Muslims, particularly, young men.

In the next section, a number of illustrations will show how the complex interaction of specific localities and social patterns of individual and multi-layered belonging shape female perspectives on British nationhood and citizenship. ${ }^{\text {vi }}$ In what 
ways do the women grasp their multidimensional and 'de-territorialized' belonging with reference to a regional, social and cultural disparity?

All interviewed women lived in London at some stage of their life. Those who live or were born in the North (Loughborough and Leeds, for example) came to London either for university studies or to start a first job. Those, who grew up in London and still live there moved temporarily to other cities while completing a university degree (Liverpool; Portsmouth) or migrated from India, for example, where first degrees were obtained (Delhi). A pattern of geographical movement is prevalent in all biographies, whether it is international migration or domestic (internal) migration. The mobility and migration frequency as documented in these narratives confirms wider patterns of internal migration with respect to South Asian Brits as the national statistic "shows whites having marginally lower migration tendencies than non-whites in the UK” (Stillwell and Hussain 2010: 1386).

Having outlined above the ways in which London works as the signifier of multicultural Britain, the North of England rather is identified with a more homogeneous (white, working class) and less cosmopolitan and metropolitan space. Reference to different spaces and places is remarkable in most narratives; Amrita for example is a human rights lawyer from Leeds, who studied in London:

"I was there for four years, and I had a great time. I was a student there, and I had lots of friends and it was good. London then was a great city. I think it is now but, it is a nicer sort of, you know, you have to make thousands and thousands, hundreds of thousands of pounds to live a really good life in London....So, yeah but Leeds, I do have a very Yorkshire side to me, too, you know, which I love, I love walking in the country here. Have you been to Bolton Abbey? It's just oh it's my favourite place in all the world isn't it?” 
Amrita arrived at the age of four in Britain. Her father was a hospital doctor from Galgadeh, India who took up a job offer to work as an NHS doctor in Hull, in 1976. Hull is a port city on the east coast of Yorkshire. Amrita grew up in the North and despite her years of academic studies in London, she lived in the North most of her life.

Her statement to have a 'Yorkshire side' makes reference to the landscape of the Dales, surrounding cities such as Leeds and Bradford and contrasting the media aired dominant image of urban deprivation and South Asian Youth's violent anger. This dominant image is largely identified with masculinity and thus operates on gendered terms. Amrita's statement of loving to walk in the English countryside expresses her regional belonging in distinctive gendered ways as 'nature' is associated with peaceful leisure activity and contains a female subtext (Räthzel 1994). Therefore, it connotes a more positive image in contrast to the 'urban' and disturbing space of a city. In addition, as a middle class female and a Brahman ${ }^{\text {vii }}$ she inhabits and inherits a culturally laden symbolic space giving her a more self confident world view resulting, at least in part, from her privileged high-caste position. Throughout the interview, Amrita expressed a clear identification with Yorkshire, her love for London, and her regional belonging, encompassing an ease with the connotation of Britain as a multicultural nation.

Other female interview partners felt much more distress about the experiences of day-to-day racism in the North. For example, they felt threatened by an increase in voting results for the extreme right wing party, the BNP. Further intersecting dimensions, such as having a darker skin complexion, coming from a lower social class or caste, or actively expressing Muslim faith impacted on the social space the women felt they could inhabit safely. 
Another example of a regional identity relates to the pride of 'being a Londoner'. Humera, born in Pakistan and co-founder of An-Niza, a Muslim women's group, came to London as a toddler. Humera has been very much engaged with politics since the 1960s and 70s. She refers, as does Amrita, to a specific regional locality. "If you are growing up in Kilburn in London, which is very diverse and complex inner city, by definition you are interested in political stuff and about things happening around. So I was sort of involved in those kinds of things to do with racism primarily.”

Though Humera studied in Portsmouth, a predominantly white port city on the southwest Coast, she returned to London after graduating and started working within an Islamic framework. In terms of Zeitgeist, she ‘rediscovered' her Muslim faith later in life after engaging previously with the black anti-racism struggle of the 1970s and 1980s as did some of the other feminist interview partners and London activists. Looking at some of An-Niza's goals, she emphasizes:

"What we say is we are an organization managed by women working for the welfare of families, so we don't exclude men from it, men have been involved over the years and for some stuff. And of course, our perspective functions to influence men, too. But what we are saying it is about creating gender harmony that is what we are interested in. So we want to look at what the blockages are in society and the reason why."

At several stages of the interview she stressed the significance of her Muslim identity as well as the relevance of the internal diversity of the Muslim community and harmony. Her strong wish to cherish a particular 'we' - Muslim community and their bonds - encompassed her pragmatic attitude concentrating on local social welfare activities. Despite her sense of Muslim faith her reference point remained the London borough where she lives. 
"And in the work that we did with Muslim women we found if you asked them, what is the issue that concerns you most for yourself? And ironically what they would say is invariably, we would like our husbands to have a job, and somebody to talk to them, they'd understand this and our sons, they don't have role models and all this kind of stuff. So the first thing they want in order for them to get on with what they want is they need those things to be resolved and they need to have a better relationship with it. So, eventually that got us on to the whole issue of, particularly, Muslim fatherhood, because we have a big problem with absentee fathers, as many other communities, but either because the marriage is not working or because the men are working a lot.”

Humera's focus on the needs of Muslim women links to an overall gendered social relationship pattern that governs larger society as well as the needs of this particular Muslim community in the London borough of Kilburn. In a hetero-normative societal framework there is a traditional expectation of women caring for the wellbeing of men and children. Majority and minority women likewise are embedded in communal tasks to support family, husbands or partners, and 'their' communities. This connotation of 'communal belonging' might be meant to assuage economic and emotional tensions arising between divergent family, community, and societal interests. Women are asked to 'integrate’ and create more cohesion ${ }^{\text {vii }}$ with reference to contradictory cultural, gender, and generational issues, for example. In that respect, Humera's testimony of what Muslim women were asking for when approaching her organization captures a more general pattern of gendered community relations.

As elucidated earlier, a regional dimension shapes notions of national and gendered belonging in Britain in particular ways. Here, the biographical locations were 
of key importance as the various sequences of migration (de-territorialization) and settlement (re-territorialization) of the interviewees altered their social position in line with different stages of life. The significance of London as the symbolic reference point to the international image of ‘multicultural Britain’, epitomising English modern commercial and post-colonial cosmopolitanism (Vieten 2012) and also conveying 'super-diversity' (Vertovec 2006) is not captured equally in the more 'white' and/ or ethnically segregated North of England. In fact, all but one of interviewees, were struggling with this tension within their own narratives. This included more positive experiences with cosmopolitan and more racially and ethnically diverse London at some point in life, and experiences of more homogenous, racially divided, culturally and socially excluding living conditions elsewhere in the country. In this context, internal migration and spatial flexibility become key assets to the female capacity and identity to express multi-layered belonging and realize social mobility.

\section{A feminist 'politics of becoming'}

The comparison between the narratives of minority/migrant women from Europe's two most vocal state advocates of multiculturalism in the 1980s, the Netherlands and Britain, shows certain similarities, but also important particularities. Women participating in both studies had been active professionals and academics in their country of residence for years. Their narratives were collected by slightly different methods (in the Netherlands through intensive writing sessions and in Britain by interviews, yet with a similar focus on narrations of identity, positioning, and belonging. The narrative approach with its biographical angle of storytelling enabled us to approach individual positioning within discursive spaces in the dynamic and multilayered manner that it presents itself. The narratives provided space for 
understanding the processes of negotiations of the past and the present and its manifestation through balancing acts between continuity and change.

The comparison between the two sets of data illustrates how the growing rigid integration and assimilative discourses in Europe focusing on 'New Integrationism' (Triadafilopoulos 2011: 864), contradicts an individual anchoring into national and local communities. Hence, ‘New Integrationism’ opposes the multi-layered belonging that shines through the narratives of the women of our studies. The narratives show how the 'migrant' women'get on with their lives' and actively search for inclusion and for participation in society. They are particularly engaged with issues they consider to be 'at stake in society'.

Yet, the historical and contextual embedding of the narratives in two national contexts make different patterns of positioning visible: whereas the point of reference of the Dutch women mainly is national identity, the British women displayed a variety of local (London and Leeds/ Yorkshire) or layered references to the national identity (differentiating between Englishness and Britishness). The UK study 'Understanding Society' (2012) ${ }^{\mathrm{ix}}$ argues in a similar direction when summarizing that 'ethnic minorities have a stronger sense of Britishness than the majority'. (2012: 14) ${ }^{\mathrm{x}}$ Even though there is a growing local reference of belonging in the Netherlands - such as identifying as an Amsterdammer - the dominant point of reference in public debates remains on the national level. This is different in the case of Britain and relates to the tentative observations outlined in the beginning. British multiculturalism and the $21^{\text {st }}$ century image of the British nation hint at a more inclusive notion of its nationality that impacts on the sense of new female citizens’ feeling at home and belonging.

Nonetheless, the individual experiences with local inclusion to the nation and its cultural image are layered with regional locality, class issues, caste, generation, 
ethnicity, and race. London is regarded by all of them as their place of national and multicultural pride despite an awareness that larger parts of the country, e.g. the North, tend to be rather white or more homogeneous social spaces. Therefore a strong regional particularity impacts on their sense of belonging cutting across different religious and ethnic communities. In terms of Britain, it seems that a more inclusive discursive space for multiple belonging exists which encourages ‘new' citizens of this study to identify as British yet in a multilayered manner.

The increased anti-Muslim and negative discourse about 'non-Western migrants' in the Netherlands operates as a source of exclusion even for citizens, who are legally included. Further, we elaborated that an increase of a one-dimensional assimilative discourse on national identity referred to as a mono-linear Dutch 'ethnoscape' goes against the dynamic and multi-layered ways of belonging that emerge from the narratives of women of our study. These women resist a notion of singular Dutch identity and show that their sources of belonging are evolving in many overlapping spaces. In their narratives, Dutch women negotiate a variety of spaces and locations and by doing so express agency in their sense of belonging.

Whereas the study of Dutch migrant women as 'new citizens' reveals an ambivalent emotional positioning created by a lack of symbolic inclusion to the Netherlands, the study concerning British 'migrant' women brought distinctive ways of belonging to the fore. British citizenship is connoted differently to Dutch nationality and - as a result - citizenship: neither Amsterdam as a cosmopolitan city nor Holland as the dominant ethno-national collective is distinguishable from an overall umbrella of Dutch nationality. In effect it is still the same; rejecting a multi-cultural, multi-layered and inclusive character. 
Further comparative research is needed to follow up these patterns more in-depth with respect to post-colonial citizenship regimes, and further, in the context of contemporary European strategies to enhance inclusion, social cohesion, and facilitate alternative institutions that support efforts from citizens 'to get on with their lives'.

All women, Dutch and British, as demonstrated here, had embarked on a process of becoming, in which different national identities and realities were being absorbed and emerged as an original state of mind and being. The different narratives and the various female journeys illustrate dynamic ways of accommodating individual agency as well as social structure. Accordingly, the notion of what it is to belong no longer corresponds to the strict boundaries of either/or nationalities. The resourcefulness of female new citizens as illustrated here combines diverse ethno-cultures and a variety of spaces as a source of belonging suggesting that they act individually as an avant-garde of an increasingly mobile contemporary society. Women’s flexibility, strength, and capacity contradict hegemonic perspectives on migrant/minority women in both countries. In this way these narratives serve as sources of inspiration to go against the often assumed determinant impact of dominant discourses on individual positioning. 


\section{References}

Anderson, B., 1983, 1991. Imagined Communities: Reflections on the Origins and Spread of Nationalism. (revised edition), London \& New York: Verso.

Alexander, C., Edwards, R. and Temple, B., 2007. Contesting Cultural Communities: Language, Ethnicity and Citizenship in Britain. Journal of Ethnic and Migration Studies, 33 (5), 783-800.

Anthias, F., 1999. Beyond unities of identity in high modernity. Identities, 6 (1), 121144.

Anthias, F., 2006. Belongings in a Globalising and Unequal World: Rethinking Translocations. In: N. Yuval-Davis, K. Kannabiran and U. M. Vieten (eds.) The Situated Politics of Belonging. London: Sage, 17-31.

Appadurai, A., 1997. Modernity at Large: Cultural Dimensions of Globalization. Minneapolis. MN: University of Minnesota Press.

Brah, A., 1996. Cartographies of Diaspora: Contesting Identities. London: Routledge. Deleuze, G. and Guattari, F., 1987. A Thousand Plateaus: Capitalism and Schizophrenia. Minneapolis: University of Minnesota Press.

Duyvendak, J. W., Engelen, E. and de Haan, I., 2008. Het bange Nederland. Amsterdam: Bert Bakker.

Essed, Ph. and Trienekens, S., 2008. 'Who wants to feel white?' Race, Dutch culture and contested identities. Ethnic and Racial Studies, 31(1), 52-72. 
Entzinger, Han, 2003 The Rise and Fall of Multiculturalism: The Case of the Netherlands. In: Christian Joppke and Ewa Morawska (eds.) Toward Assimilation and Citizenship: Immigrants in Liberal Nation-States. Houndmills: Palgrave Macmillan, 5987.

Geddes, A. and Favell, A., 1999. The Politics of Belonging: Migrants and Minorities in Europe. Aldershot: Ashgate.

Hall, S., 1990. Cultural Identity and Diaspora. In: J. Rutherford (ed.) Identity: Community, Culture, Difference. London: Lawrence and Wishart, 222-237. Kannabiran, K., 2006. A cartography of Resistance: the National Federation of Dalit Women. In: N. Yuval-Davis, K. Kannabiran and U. M. Vieten (eds.) The Situated Politics of Belonging. London: Sage, 54-71.

Kim, N.-K., 2010. Deliberate multiculturalism in New Labour’s Britain. Citizenship Studies, 15 (1), 125-144.

Kim-Puri, H.J., 2005. Conceptualizing gender-sexuality-state-nation: An introduction. Gender \& Society, 19 (2), 137-159.

Koshy, S., 2008. Introduction. In: Susan Koshy and R. Radhakrishnan (eds.)

Transnational South Asians - The Making of a Neo-Diaspora. Oxford: Oxford University Press, 1-41.

Kostakopoulou, D., 2010. Matters of Control: Integration Tests, Naturalisation reform and Probationary Citizenship in the United Kingdom. Journal of Ethnic and Migration Studies 36 (5), 829-846.

Linklater, A., 2002. Cosmopolitan citizenship. In: E.F. Isin and B.S. Turner (eds.) Handbook of Citizenship Studies. London: Sage, 191-207. 
Lister, M. R., Anttonen, A., Bussemaker J. and Gerhard, U., 2007. Gendering

Citizenship in Western Europe - New Challenges for citizenship research in a crossnational context. Bristol: Policy Press.

Lutz, H., 1999. The Limits of European-ness: Immigrant women in Fortress Europe. Feminist Review, 57, 93-111.

Marshall, T. H., 1950. Citizenship and Social Class. Cambridge: Cambridge University Press.

Malkki, L., 1995. Refugees and Exile: From 'Refugee Studies’ to the National Order of Things. Annual Reviews Anthropology, 24, 495-523.

Mitchell, K., 1997. Transnational discourse: Bringing geography back in. Antipode, 29 (2), 101-114.

Nava, M., 2007. Visceral Cosmopolitanism -Gender, Culture and the Normalisation of Difference. London: Berg.

Rapport, N. and Dawson, A., 1998. Migrants of Identity: Perceptions of Home in a World of Movement. Oxford: Berg.

Räthzel, N., 1994. Harmonious 'Heimat' and Disturbing 'Ausländer'. Feminism \& Pscyhology, 4 (1), 81-98.

Roggeband, C. and Verloo, M., 2000. Dutch women are liberated, migrant women are a problem: the evaluation of policy frames on gender and migration in the Netherlands (1995-2005). Social Policy and Administration, 3, 271-288.

Stevenson, N., 2003. Cultural Citizenship. Maidenhead: Open University Press. Stillwell, J. A, and Hussain, S., 2010. Exploring the Ethnic Dimension of Internal Migration in Great Britain using Migration Effectiveness and Spatial Connectivity. Journal of Ethnic and Migration Studies, 36 (9), 1381-1403. 
Stolke, Verena, 1995. Talking Culture: New Boundaries, New Rhetorics of Exclusion in Europe. Current Anthropology, 36 (1), 1-24.

Triadafilopoulos, T., 2011. Illiberal Means to Liberal Ends? Understanding recent Immigrant Integration Policies in Europe. Journal of Ethnic and Migration Studies, 37 (6), 861-880.

Vasta, E., 2007. From ethnic minorities to ethnic majority policy: Multiculturalism and the shift to assimilationism in the Netherlands. Ethnic and Racial Studies, 30 (5), 713740.

Vertovec, Sr., 2007. Super-diversity and its implications. Ethnic and Racial Studies, 30 (6), 1024-1054.

Vieten, U. M., 2006. ”Out in the Blue of Europe”: modernist cosmopolitan identity and the deterritorialization of belonging, Patterns of Prejudice, vol. 40 (3), 259-279.

Vieten U. M., 2012. Gender and Cosmopolitanism in Europe, Farnham: Ashgate.

Vieten, U. M. , 2013 forthcoming, "When I land in Islamabad I feel home and when I land in Heathrow I feel home” - gendered belonging and diasporic identities of South Asian British citizens in London and North England’, in: Georgina Tsolidis (ed), Living Diaspora - family, education and identity, Netherlands: Springer.

Yuval-Davis, N., Anthias, F. and Kofman, E., 2005. Secure Borders and Safe Haven and the Gendered Politics of Belonging: Beyond Social Cohesion. Ethnic and Racial Studies, 28 (3), 513-535.

Yuval-Davis, N., Kannabiran, K. And U. M. Vieten, 2006. Introduction to 'The Situated Politics of Belonging', London: Sage.

Yuval-Davis, N. and Werbner, P., 1999. (eds.) Women, Citizenship, Difference, London: Zed books. 
'Anitha, one of the British interviewees pronounced this explicitly with 'having a stake in the country'. ii With respect to the dominant discourse we use the term 'migrant' to position the women, nonetheless, being aware that this is a category not fully adequate.

iii We are using Andersen and Siim's (2004: 2) definition of empowerment as 'the process of awareness and capacity building, which increases the participation and decision-making power of citizens and may potentially lead to transformative action which will change opportunity structures in an inclusive and equalising direction.'

iv http://www.dutchnews.nl/news/archives/2012/03/eu_parliament_wants_rutte_to_d.php, visited on March $14^{\text {th }}, 2012$.

${ }^{v}$ Different official reports on community cohesion (Cantle report 2006; Oldham Independent Review 2001; Ouseley Report 2001) set up in the aftermath of the Northern Riots address the causes of those local 'disturbances'.

${ }^{\text {vi }}$ As far as London and North England is concerned, in total, nine female South Asian British citizens were interviewed; six were based in London. Religious heritage varied from Sikh, Muslim, and a background in Hinduism. All but one, were aged between 40 and 55 .

vii This is the highest caste according to Hinduism.

viiiThe Cantle Report $(2006: 6$, 8) stresses the role women have to play in working towards a more cohesive community, the need to engage with youth and also the investment in leadership.

ix http://www.understandingsociety.org.uk/

${ }^{\mathrm{x}}$ http://research.understandingsociety.org.uk/findings/findings-2012 